\title{
ANDREJ BOTEK*
}

\section{Metod, arcibiskup „cirkvi moravskej“ a (vel'ko)moravský katedrálny chrám}

BOTEK, A.: Method, Archbishop of the „Moravian Church“ and the (Great)Moravian Cathedral. Slavica Slovaca, 56, 2021, No 2, pp. 191-204 (Bratislava).

Pope John VIII. summoned Method in June 879 from Great Moravia to Rome concerning to complaints from the Bavarian clergy. In his letter he named Methodius as „Archbishop of the holy Pannonian Church“ Method came to Rome in the official embassy with the nobleman Zemežizeň. The subsequent events in 880 in Rome were in many way groundbreaking for the ecclesiastical and political development in Great Moravia as well. Pope informed Svätopluk in the bull Industriae tuae he is taking his empire under Roman patronage, what meant an immense strengthening in international relations and de facto acknowledgement its independence. At the same time, Method defended himself in all points. Pope confirmed his orthodoxy, allowed the Slavonic liturgy and for the first time named Method as "Archbishop of the holy Moravian Church". He announced to Svätopluk, Wiching was consecrated for the "holy Nitra Church" as the sufragan of Method. By this act an independent Great Moravian archdiocese was established in ecclesiastical law with its solid structures. The article deals with the circumstances that led to a change in the perspective of papal policy. It is also devoted to the issue of the location of the Methods cathedral. Not only analyzes of hitherto known findings of Great Moravian churches are used, but also a description of the burial place of Archbishop Method, who was buried in his main temple.

Great Moravia, Method, Archbishopric, Moravian Church, Cathedral, Methods grave.

Arcibiskup a pápežský legát Metod pôsobil od roku 874 na Vel'kej Morave v napätí s bavorským klérom, ktorý útočil najmä na slávenie liturgie v slovienskom/staroslovienskom ${ }^{1}$ jazyku, podozrieval ho však aj z heretického učenia a tieto svoje námietky zasielal zrejme formou st’ažností do Ríma. Napätie medzi arcibiskupom a pápežským legátom Metodom a franskými kňazmi vnímal negatívne aj Svätopluk, nielen z dôvodu náboženského, ale hlavne z dôvodu politického - posilňoval svoje mocenské postavenie, výbojmi rozširoval svoje územie a na tieto svoje mocenské podujatia potreboval vnútornú stabilitu v ríši. Názorové disproporcie medzi duchovenstvom dvojakej orientácie vnímal zrejme predovšetkým z tohto hl'adiska a nie v ich teologických súvislostiach. Svätopluk sa pravdepodobne na radu svojho radcu Jána z Benátok rozhodol predložit' kauzu na posúdenie Rímu. Bol to totiž kňaz Ján z Benátok, ktorý do Ríma prišiel ako Svätoplukov vyslanec a informoval pápeža o pochybnostiach, ktoré má Svätopluk v otázkach pravej viery - iste následkom zmienených názorových konfrontácií medzi Metodom a franskými kňazmi. Vyplýva to z pápežovho listu zo dňa 14. júna 879 Svätoplukovi. Pá-

\footnotetext{
* Doc. Mgr. Ing. arch. Andrej Botek, PhD., Fakulta architektúry a dizajnu STU, Ústav dejín a teórie architektúry a obnovy pamiatok, Nám. slobody 19, 81245 Bratislava.

${ }^{1} \mathrm{~V}$ ostatnom čase niektorí autori termín „sloviensky“ nahradzujú výrazom „slovanský“. V predkladanom príspevku ostávame pri zaužívanom termíne „starosloviensky“, nakol'ko je stále používaný v odbornej spisbe (napr. DudášováKriššáková, J.: Od staroslovienčiny k cirkevnej slovančine. In: Slavica Slovaca, 2019, roč. 54, č. 2, s. 156-165). Výraz „sloviensky“ ponechávam len v prípade citovania.

${ }^{2}$ Bartoňková, D. - Večerka, R. (eds.): Magnae Moraviae Fontes Historici III. Diplomata. Epistolae. Textus Historici Varii. Edicio secunda, revisa et aucta. Prameny k dějinám Velké Moravy III. Listiny, listy, různé historické texty. Druhé, revidované a rozšířené vydání. Praha: KLP, 2011, s. 153-156; Ratkoš, P.: Pramene k dejinám Vel'kej Moravy. Bratislava: SAV, 1964, s. 189. Niektorí autori zastávajú názor, že Ján z Benátok v podstate obvinenia voči Metodovi potvrdil.
} 
pež Svätopluka nielen uist'uje o svojej priazni a modlitbách, ale súčasne ho povzbudzuje verit' tradičnému učeniu, ktoré sa „svätá rímska cirkev od samého kniežat’a apoštolov naučila...“.”3 V rovnaký deň adresoval pápež Ján VIII. list Metodovi, ktorým ho povolal do Ríma, aby sa zodpovedal z obvinení. $Z$ tónu listu sa dá usudzovat', že tieto obvinenia boli vážne. ${ }^{4}$ Hoci Metod pôsobil na Vel'kej Morave už aspoň 6 rokov, pápež mu list adresuje slovami: „Najdôstojnejšiemu Metodovi, arcibiskupovi panónskej cirkvi“ “. ${ }^{5}$ Uvažujúc nad obsahom oboch listov je jasné, že odrážajú spor medzi Metodom a bavorským klérom pôsobiacim na Vel'kej Morave. ${ }^{6}$ Franskí kňazi pôsobili na Vel'kej Morave už od začiatku 9., stor. a preto činnost' misie byzantských bratov a neskôr Metoda vnímali ako nevítanú konkurenciu. ${ }^{7}$ Hoci povaha tohto sporu, jeho príčiny a priebeh je materiálom na samostatnú štúdiu, a to nielen z cirkevno-právnej oblasti, v tomto príspevku sa mu nebudeme podrobnejšie venovat'.

Roku 880 neprichádza do Ríma Metod sám, ale v oficiálne vyslanom sprievode na čele s vel'možom Zemežízňom. ${ }^{8}$ Ide teda o spoločnú akciu, zrejme koordinovanú Svätoplukom. Do Ríma putuje aj Wiching, ${ }^{9}$ pričom z formulácií následného listu pápeža Jána VIII. Svätoplukovi z júna roku 880, známom ako Industriae tuae, nie je úplne zrejmé, či Wiching bol súčast’ou posolstva vedeného Metodom a Zemežízňom, alebo šiel vlastnou cestou, napr. s deputáciou bavorského kléru, pôsobiaceho na Vel'kej Morave. Pápež totiž o ňom Svätoplukovi píše ako o kňazovi ,... ktorého si k nám poslal...". ${ }^{10} \mathrm{Z}$ toho vyplýva, že Wiching nešiel do Ríma súkromne, ale v Svätoplukovom poverení. $\mathrm{O}$ tom, či bol súčastou spomenutého vel'komoravského posolstva, alebo

Č́ák, M.: Kultúrne a politické dedičstvo sv. Cyrila a Metoda vo vzt’ahu k našej štátnosti. In Lukáčová, M. - Husár, M. - Ivanič, P. - Hetényi, M. (eds.): Tradícia a prítomnost' misijného diela sv. Cyrila a Metoda. Nitra: UKF, 2013 , s. 664. Existuje aj opačný názor, že Ján šiel do Ríma preto, aby Metoda obhájil. Charvát, P.: A montibus usquae ad mare: Morava a Benátky v 9. století. In Kourril, P. et al. (eds.): Cyrilometodějská misie a Evropa: 1150 let od prríchodu soluňských bratří na Velkou Moravu. Brno: AÚ AV ČR, 2014, s. 227.

${ }^{3}$ Bartoňková, D. - Večerka, R. (eds.): Magnae Moraviae Fontes Historici III, c. d., s. 154; Ratkoš, P.: Pramene k dejinám Vel'kej Moravy, c. d., s. 189.

${ }^{4}$ Bartoňková, D. - Večerka, R. (eds.): Magnae Moraviae Fontes Historici III, c. d., s. 156-157; Ratkoš, P.: Pramene k dejinám Vel'kej Moravy, c. d., s. 188. Pápež používa pomerne ostré formulácie ,...dozvedeli sme sa, že pri vyučovaní neučíš to, čo svätá rímska cirkev ... ba sám l'ud privádzaš do bludu. ... Dozvedáme sa tiež, že omše spievaš v barbarskom, čiže slovienskom jazyku."V závere listu však pápež povol'uje Metodovi kázat'v reči l'udu.

${ }^{5}$ Bartoňková, D. - Večerka, R. (eds.): Magnae Moraviae Fontes Historici III, c. d., s. 156; Ratkoš, P.: Pramene k dejinám Vel'kej Moravy, c. d., s. 189. Bližšie k problematike panónskej ordinácie pozri Botek, A.: Metodova panónska ordinácia a otázky situovania sídelného chrámu. In: Slavica Slovaca, 2020, roč. 55, č. 3, s. 435-451.

${ }^{6}$ Po tzv. „Dunajskej synode“ z roku 796 sa bavorské diecézy dohodli s Aquileou na rozdelení pôsobenia v priestore bývalého Avarského kaganátu ako i slovanských území. Na teritóriu neskoršej Vel'kej Moravy získali postupne dominanciu pasovskí klerici, i ked’ istú dobu tu zasahovali i kňazi zo Salzburgu. Špetko, J.: Kristianizácia Slovienov v predcyrilometodskom období (od 5. až do polovice 9. storočia). In: Kružliak, I. - Hnilica, J. (eds.): Prvoučitel’ národa slovenského. Zborník na pamiatku tisícstého výročia smrti sv. Metoda. Rím: Unitas et Pax, 1988, s. 29; Ivanič, P.: Christianization of the territory of today's Moravia and Slovakia before 863. In: Bogoslovni vestnik, 2020, Vol. 80, N. 3, s. 660 ; Кардаш, О.: Проблема розмежування місіонерських сфер впливу латинських церковних діоцезів на пост-аварському просторі першої половини IX ст. In: Українсько-угорські етюди. Вип. 3. Львів: Інститут українознавства, 2019, s. 10-11.

${ }^{7}$ Niektorí autori zastávajú názor, že v prvopočiatkkoch pôsobenia solúnskych bratov na Vel'kej Morave $\mathrm{k}$ stretom s bavorským duchovenstvom nedochádzalo. Marsina, R.: Zápas o používanie slovanského jazyka v liturgii na Vel’kej Morave. In Lukáčová, M. - Husár, M. - Ivanič, P. - Hetényi, M. (eds.): Tradícia a prítomnost’ misijného diela sv. Cyrila a Metoda. Nitra: UKF, 2013, s. 104; Jáger, R.: Časové vymedzenie vzniku vel'komoravského Nomokánona. In: Konštantínove listy/Constantine's letters, 2018, roč. 11, č. 2, s. 73.

${ }^{8}$ Č́ky, M.: Kultúrne a politické dedičstvo sv. Cyrila a Metoda vo vzt’ahu k našej štátnosti, c. d., s. 665.

${ }^{9}$ Medzi historikmi sa o ňom často píše ako o benediktínovi „švábskeho pôvodu“ (napr. Marsina, R.: Metodov boj. Bratislava: Obzor, 1985, s. 72), pritom dobové správy ho uvádzajú ako Ostrogóta, resp. Alemana (Ratkoš, P.: Pramene k dejinám Vel'kej Moravy, c. d., s. 112).

${ }^{10}$ Bartoňková, D. - Večerka, R. (eds.): Magnae Moraviae Fontes Historici III, c. d., s. 169; Ratkoš, P.: Pramene k dejinám Vel'kej Moravy, c. d., s. 191. 
prišiel samostatne, nemáme presné informácie, i ked' viacerí autori jeho účast' v oficiálnej delegácii pripúšt’ajú. ${ }^{11} \mathrm{~V}$ Ríme sa v podstate zopakoval úspech, ktorý dosiahli solúnski bratia v roku 868. Avšak rímsky pobyt priniesol dôležité skutočnosti aj v cirkevno - správnej a tiež v, ,štátnej“ oblasti. Situáciu reflektuje už zmienený pápežov list Industriae tuae z júna 880, z ktorého vyplývajú nasledovné skutočnosti:

Metod sa obhájil vo všetkých obžalobách, osvedčil svoju pravovernost' a pápež povolil aj používanie staroslovienskeho jazyka pri bohoslužbách. ${ }^{12}$ Znamená to, že st’ažnosti bavorského kléru boli vyvrátené. Nevieme presne, akých teologických otázok sa týkali, predpokladáme však, že šlo aj o formuláciu „Filioque“ v Crede. ${ }^{13}$ Mohli sa však týkat’ aj iných vieroučných otázok. Druhou skutočnost'ou bola kauza staroslovienskej liturgie. Aj tú Metod obhájil, dokonca pápež sám argumentuje v jej prospech okrem iného aj slovami: „Ved’ ani viere, ani náuke nijako neprekáža, či už omše spievat' v tomže slovienskom jazyku, či čítat' sväté evanjelium alebo sväté čítania Nového alebo Starého zákona správne preložené a vysvetl'ované." ${ }^{14}$ List je však s pápežovým dovetkom v tom zmysle, že evanjelium sa má čítat’ najprv latinsky a pre Svätopluka, ak si žiada, sa majú omše slúžit' len latinsky. ${ }^{15}$

Dôležitou súčast'ou sú pápežove zásahy do cirkevno - správnej štruktúry. Pápež informuje Svätopluka o potvrdení Metoda v postavení arcibiskupa a súčasne uvádza: „Aj toho kňaza Wichinga, ktorého si k nám poslal, vysvätili sme ako zvoleného biskupa svätej cirkvi nitrianskej; prikázali sme mu, aby svojho arcibiskupa vo všetkom poslúchal..."16 Pápež súčasne povzbudzuje Svätopluka, aby poslal i iného kňaza alebo diakona, vhodného na biskupské svätenie, ,... aby spomenutý váš arcibiskup mohol s týmito dvomi nami vysvätenými biskupmi ... vysväcovat' pre iné miesta, v ktorých biskupi majú a môžu dôstojne žit'." ${ }^{17} \mathrm{Z}$ uvedenej formulácie vyplýva,

${ }^{11}$ Napr. Čáky, M.: Kultúrne a politické dedičstvo sv. Cyrila a Metoda vo vzt’ahu k našej štátnosti, c. d., s. 665; Judák, V.: Filioque - cesta k rozkolu? In Lukáčová, M. - Husár, M. - Ivanič, P. - Hetényi, M. (eds.): Tradícia a prítomnost' misijného diela sv. Cyrila a Metoda. Nitra: UKF FF, 2013, s. 522.

${ }^{12}$ Bartoňková, D. - Večerka, R. (eds.): Magnae Moraviae Fontes Historici III, c. d., s. 172-173; Marsina, R.: Zápas o používanie slovanského jazyka v liturgii na Vel'kej Morave. c. d., 2013, s. 107.

${ }^{13} \mathrm{Na} 1$. Konštantínopolskom sneme v roku 381 sa prijala do Creda formulácia o Sv. Duchu, že vychádza z Otca. V západnej časti Cirkvi sa najmä v polemike s viacerými herézami postupne vyvíjala spresňujúca trinitárna teológia. Formulácia „z Otca i Syna - Filioque“ sa objavila v osobnom vyznaní vizigótskeho panovníka Rekkareda na toledskej synode (589) a všeobecnejšie sa začala používat' od synody v Brage (674), a to hlavne proti arianizmu. Ten na východe zaniká v priebehu 4. stor., ale na západe pôsobí v d'alších storočiach najmä medzi Germánmi. Pozri Krupa, J.: Súčasné ekumenické perspektívy riešenia otázky Filioque. In: ACTA Facultatis Theologicae Universitatis Comenianae Bratislavensis, 2001, roč. 1, č. 2, s. 140141; Judák, V.: Filioque - cesta k rozkolu?, c. d., s. 509. Formuláciu Filioque východní teológovia striktne odmietali a učili, že Duch pochádza z Otca skrze Syna. Z teologického sporu sa postupne stal spor dogmatický. Vyostril sa hlavne v súvislosti s napätím medzi Karolom Vel'kým a byzantskou cisárovnou Irenou po 797 (porov. Šafin, J.: Teológia epochy Karolingovcov. Karolingovská duchovná kultúra, prvý náčrt „Mesta Božieho“ a protirečenia ríše Karola Vel'kého. In: Historia Ecclesiastica, 2013, roč. IV, č. 2, s. 12), čo sa odrazilo aj v teologickom spore, kde franské duchovenstvo spochybňovalo Grékov práve kvôli odmietaniu Filioque. Pápež Lev III. považoval obe formulácie za rozličné vyjadrenie jednej skutočnosti, ale s ohl'adom na Grékov odporúčal Frankom nepoužívat' v liturgii Credo a jeho znenie nechal roku 810 vyryt' na strieborné tabule bez Filioque. Spory nanovo rozprúdil patriarcha Fótios, ktorý Filioque využil v boji proti Rímu, ktorý neuznal jeho ordináciu. V hre bol aj spor o vplyv v Bulharsku. V Ríme sa však v tom čase Credo spievalo bez Filioque, takže Metod, hoci formovaný východnou spiritualitou, $\mathrm{v}$ tomto zmysle nebol v rozpore s rímskou praxou. Je možné, že východofranskí kňazi obviňovali Metoda z herézy kvôli osobe Fótia. Judák, V.: Filioque - cesta k rozkolu?, c. d., s. 508-509 a 519.

${ }^{14}$ Bartoňková, D. - Večerka, R. (eds.): Magnae Moraviae Fontes Historici III, c. d., s. 173; Ratkoš, P.: Pramene k dejinám Vel'kej Moravy, c. d., s. 192.

${ }^{15}$ Bartoňková, D. - Večerka, R. (eds.): Magnae Moraviae Fontes Historici III, s. 173; Ratkoš, P.: Pramene k dejinám Vel'kej Moravy, c. d., s. 192.

${ }^{16}$ Bartoňková, D. - Večerka, R. (eds.): Magnae Moraviae Fontes Historici III, c. d., s. 170; Ratkoš, P.: Pramene k dejinám Vel'kej Moravy, c. d., s. 191.

${ }^{17}$ Bartoňková, D. - Večerka, R. (eds.): Magnae Moraviae Fontes Historici III, c. d., s. 170-171; Ratkoš, P.: Pramene k dejinám Vel'kej Moravy, c. d., s. 191; Betti, M.: La formazione della sancta ecclesia Marabensis (858-882). Fonti e linguaggi di un progetto papale. Paris: Université Paris 1, Panthéon - Sorbonne, s. 206. 
že tu nejde o udelenie osobnej biskupskej titulatúry, ale o zriadenie novej cirkevnej provincie s arcibiskupom, jemu podriadeným biskupom a výhl'adovo i d'alšími biskupmi podl'a aktuálnej potreby. ${ }^{18}$ Ťažiskový je úvod pápežovho listu, v ktorom Metoda oslovuje „Najdôstojnejší arcibiskup svätej cirkvi moravskej“. ${ }^{19}$ Tento titul použil pápež prvý krát . Vzhl'adom na skutočnost', že vo všetkých dovtedajších listoch menuje Metoda arcibiskupom „cirkvi panónskej“, hoci reálne pôsobil na Vel'kej Morave a nie v Panónii, je to indícia toho, že počas pobytu v Ríme došlo $\mathrm{k}$ dôležitej zmene pápežskej optiky.

Prijatie Svätoplukovej dŕžavy pod priamy patronát Ríma považujú viacerí autori tradične za uznanie zahraničnopolitického postavenia Svätoplukovej „ríše“ ako suverénneho útvaru, nezávislého od iných vládcov, najmä od Východofranskej ríše. ${ }^{20}$ Svedčit' o tom má oslovenie Svätopluka vo forme „Milovanému synovi Svätoplukovi, slávnemu vladárovi“. ${ }^{21}$ Tým, že Svätoplukovo domínium malo uznanie pápeža, ktorý bol nástupcom apoštola Petra a ten bol za hlavu cirkvi ustanovený Kristom, dôvodia niektorí, že bola legitimita potvrdená najvyššou duchovnou autoritou. ${ }^{22}$ Samozrejme, Svätoplukovo postavenie tým nebolo vyššie ako v prípade franských panovníkov. V kontexte prijatia Svätoplukovej „ríše“ pod rímsky patronát považujeme za vysoko pravdepodobnú potrebu upravit’ aj cirkevné pomery. Sme toho názoru, že dŕžava už nemohla vystačit' s nejasne definovaným postavením ,postmisijného“ územia bez diecéznych štruktúr. Ustanovenie vlastnej územnej diecéznej organizácie môže nepriamo odrážat' aj určitý stupeň dosiahnutého „štátotvorného“ vývoja.

Viacerí autori predpokladajú, že myšlienka patronátu Ríma nad Svätoplukovým domíniom bola Metodovým nápadom, ${ }^{23}$ ked’že mal právnické vzdelanie a aj sám zanechal viaceré spisy právneho (cirkevného i svetského) charakteru. ${ }^{24}$ Svedčit’ o tom má i spoločná účast' Metoda v ,štátnom“ posolstve s vel'možom Zemežízňom, ktorý mal v Ríme tlmočit' Svätoplukove požiadavky. Znamenalo by to teda predpokladat', že koncepcia samostatnej cirkevnej provincie i prijatie rímskeho patronátu bola stratégia, na ktorej sa dohodli ešte na Vel'kej Morave Metod i Svätopluk, ${ }^{25}$ a teda boli v tomto zmysle spojencami. Potom nás ale prekvapuje skutočnost', že Wichinga poslal do Ríma Svätopluk, ako to vyplýva z už spomenutej pápežovej formulácie v liste. Svätopluk predsa vedel, že Wiching je Metodov odporca a v Ríme nebude vystupovat' v Metodov prospech.

\footnotetext{
${ }^{18}$ Ivanič, P.: Christianizácia územia Moravy a Slovenska - od misií k arcibiskupstvu. In Glejtek, M. a kol.: Arcibiskupi a biskupi Uhorska. Moc prelátov a jej prejavy v stredoveku. Bratislava: PostScriptum, 2020, s. 46; Ivanič, P.:The origins of Christianity in the territory of Czech and Slovak Republics within the context of written sources. In: European Journal of Science and Theology, 2016, Vol. 12, N. 6, s. 128.

${ }^{19}$ Bartoňková, D. - Večerka, R. (eds.): Magnae Moraviae Fontes Historici III, c. d., s. 156; Ratkoš, P.: Pramene k dejinám Vel'kej Moravy, c. d., s. 190, Betti, M.: La formazione della sancta ecclesia Marabensis (858-882), c. d., s. 175.

${ }^{20}$ Napr. Č́ky, M.: Kultúrne a politické dedičstvo sv. Cyrila a Metoda vo vzt’ahu k našej štátnosti, c. d., s. 666.

${ }^{21}$ Bartoňková, D. - Večerka, R. (eds.): Magnae Moraviae Fontes Historici III, c. d., s. 153; Ratkoš, P.: Pramene k dejinám Vel'kej Moravy, c. d., s. 190; Kučera, M.: Postavy vel'komoravskej histórie. Bratislava: Osveta, 1986, s. 202.

${ }^{22}$ Steinhübel, J.: Moravania, Chorváti a Bulhari v plánoch pápežskej kúrie (860-880). In Panis, B. - Ruttkay, M. - Turčan, V. (eds.): Bratia, ktorí menili svet - Konštantín a Metod. Bratislava: SNM, Nitra: AÚ SAV, 2012, s. 174. Viacerí autori poukazujú na skutočnost', že podobné postavenie priznal pápež aj anglosaským král'om či chorvátskemu Branimírovi. Súhrnne Gábriš, T. - Jáger, R.: Vel'ká Morava medzi kmeňom a štátom. Historickoprávna a historicko - lingvistická analýza. In: Acta Facultatis Iuridicae Universitatis Comenianae, 2016, tom. XXXV, č. 1, s. 57. Na tomto mieste sa však nemienime venovat' podrobným analýzam charakteru organizácie Svätoplukovho domínia, k čomu existuje bohatá literatúra.

${ }^{23}$ Napr. Bagin, A.: Apoštolové Slovanů Cyril a Metoděj a Velká Morava. Praha: Česká katolická charita, 1982, s. 103.

${ }^{24}$ Zakon sudnyj l’udem, Nomokánon, v istom zmysle i Napomenutie vladárom a Príkazy svätých otcov. Havlíková, L.: Crimen laese maiestatis a panovník jako garant práva ve velkomoravském prostředí 9. století. In: Konštantínove listy/ Constantine's letters, 2011, roč. 4, č. 2, s. 42-43; Vragaš, Š.: Cyrilometodský jazyk na Vel'kej Morave. In Kružliak, I. Hnilica, J. (eds.): Prvoučitel' národa slovenského. Zborník na pamiatku tisícstého výročia smrti sv. Metoda. Rím: Unitas et Pax, 1988, s. 199-200.

${ }^{25}$ Jáger, R.: Vzt'ah vládnej moci a cirkvi na Vel'kej Morave. In: Slavica Slovaca, 2019, roč. 54, č. 1, s. 6.
} 
Viacerí bádatelia predpokladajú, že Wiching bol členom posolstva, ktoré viedli Zemežízeň a Metod, a mohol byt' „záložným“ riešením Svätopluka pre prípad, že by sa Metod v Ríme neobhájil. ${ }^{26}$ Koncepcia samostatnej provincie by sa v takom prípade zrútila, a teda ,prezieravý“ Svätopluk pripravil pre takýto prípad Wichinga, ktorý bol, ako zástanca latinskej liturgie, akceptovatel'ný. Nie je vylúčené, že Svätopluk hral v istom zmysle na obe strany. Metoda potreboval ako protiváhu bavorského kléru a záruku cirkevnej svojbytnosti ríše. V tomto zmysle bol pre neho Metod aj politickou legitimitou oproti pozíciám Východofranskej ríše a súčasne ako legát pre slovanské krajiny mohol legitimovat' Svätoplukove výboje. ${ }^{27}$ Toleranciou prítomnosti východofranských duchovných udržoval zasa mierový stav s král'om Karolom Tučným, ktorý potreboval na upevňovanie moci i na vonkajšie výboje. Je však možná aj iná hypotéza, že totiž Wiching sa do Ríma vybral až po odchode Svätoplukovho posolstva a že vytvorenie nitrianskeho biskupstva bola Wichingova myšlienka. Svätopluk pôvodne azda myslel len na zriadenie cirkevnej provincie v rámci územia svojej ríše, na čo by postačovala Metodova jurisdikcia a na takomto riešení sa pravdepodobne s Metodom dohodol. Wiching mohol využit' Metodov odchod a presvedčit' Svätopluka o vhodnosti zriadenia biskupstva v Nitre a jeho (Wichingovej) biskupskej vysviacky. Posilnil by tým nielen komunitu východofranských kňazov v Nitre, ale stal by sa dôležitým cirkevným hodnostárom a lepšie mohol protirečit' Metodovým ustanoveniam. Svätopluk si možno uvedomil, že nemá zaručené, že sa Metod v Ríme obháji, a tak by jeho úsilie mohlo vyjst' naprázdno. Mohol by to byt' dôvod „záložného“ postavenia Wichinga, ak by nevyšiel zámer s Metodom v prípade, že ho kúria odsúdi. Neskorší Wichingov príchod do Ríma by mohol vyplývat’ z už spomenutej pápežovej poznámky v listine Industriae tuae. Na druhej strane by to ale mohlo vyjadrovat' aj skutočnost', že Svätopluk si od začiatku prial Wichingove svätenie a preto ho poslal do Ríma s touto požiadavkou. ${ }^{28} \mathrm{~S}$ ideou nitrianskeho biskupstva mohol íst' Wiching aj v sprievode oficiálneho posolstva Metoda a Zemežízňa. Dobové dokumenty o presnejších okolnostiach mlčia.

Už sme spomínali, že pápež Ján VIII. vnímal Metoda až do roku 880 ako panónskeho arcibiskupa, o čom svedčia formulácie všetkých jeho listov. A to napriek skutočnosti, že Metod najneskôr od roku 874 mohol pôsobit' len na Vel'kej Morave. Aktivity v Panónii mohol rozvinút' až po roku 882/883, kedy jej vel'kú čast' anektoval Svätopluk - k tomu však došlo až po rímskych udalostiach z roku 880. Možno tu vidiet' aj pápežovu snahu udržat’ vplyv kúrie v Panónii pred rozpínajúcou sa aktivitou bavorského episkopátu. ${ }^{29}$ Náhla zmena pápežovho názoru zrejme spočíva vo vonkajších okolnostiach - konkrétne v požiadavke vel'komoravského posolstva. Predpokladáme, že Metod sa sústredil najmä na obranu svojej pravovernosti a staroslovienskej liturgie a že otázku cirkevného zriadenia predniesol spolu so žiadost'ou o rímsku patronáciu nad Vel'kou Moravou Zemežízeň. Pápež si asi uvedomil, že cirkevný hierarcha potrebuje v tomto priestore na pokojné pôsobenie ochranu svetského vládcu a tú Metodovi nemal v Panónii kto zabezpečit'. ${ }^{30}$ Naopak, toto vedel garantovat' Svätopluk pre svoje územie. Pápež preto opustil ,panónsku“ politiku a rozhodol sa vybudovat' zázemie pre vplyv Ríma na Vel'kej Morave, čím súčasne ukázal odhodlanie

\footnotetext{
${ }^{26}$ Kučera, M.: Postavy vel'komoravskej histórie, c. d., s. 201.

${ }^{27}$ Č́ky, M.: Kultúrne a politické dedičstvo sv. Cyrila a Metoda vo vzt’ahu k našej štátnosti, c. d., s. 663.

${ }^{28}$ R. Jáger predpokladá, že Wiching bol za biskupa zvolený vel'možmi a panovníkom - Svätopluk teda nemohol priamo určit' biskupa, ale mohol kandidáta odporučit' a zúčastnit' sa vol’by. Jáger, R.: Vzt'ah vládnej moci a cirkvi na Vel'kej Morave, c. d., s. 6.

${ }^{29}$ Už v listoch z roku 873 bavorským biskupom, vojvodovi Karolmanovi a královi L'udovítovi Nemcovi pápež prízvukoval, že Panónia je oddávna pod rímskou jurisdikciou. Ratkoš, P.: Pramene k dejinám Vel'kej Moravy, c. d., s. 178-181.

${ }^{30}$ Gallusová, M. - Herucová, A.: Konštantín a Metod v Panónii - zastavenie u Kocel’a. In Lukáčová, M. - Husár, M. Ivanič, P. - Hetényi, M. (eds.): Tradícia a prítomnost' misijného diela sv. Cyrila a Metoda. Nitra: Univerzita Konštantína Filozofa v Nitre, 2013, s. 119.
} 
kúrie neopustit’ stredoeurópsky priestor, kde bol konkurentom východofranský episkopát. Toto riešenie nebolo asi jeho pôvodným zámerom, pristúpil k nemu až na podnet vel'komoravského posolstva. S najväčšou pravdepodobnost'ou tento návrh predniesol vel'mož Zemežizeň v súvislosti so žiadost’ou o rímsky patronát. Pápež tu mohol vidiet' aj lepšie postavenie Ríma v novozískavaných slovanských krajinách, kde zrejme väčšie úspechy očakával od Svätopluka ako od Frankov. Bádatel'ka M. Betti dokladá, že pápež tým pokročil z misijne chápanej diecézy k diecéze teritoriálnej, pričom uprednostnil pri jej tvorbe etnický základ, kde Svätopluk predstavuje panovníka „etnickej skupiny Moravanov. “"31 Každopádne, až od tejto udalosti možno hovorit’ o (vel'ko)moravskej arcidiecéze $v$ jej pevných územných štruktúrach. To, samozrejme, nevylučovalo činnost' arcibiskupa Metoda výhl'adovo aj na oblasti anektované v budúcnosti Svätoplukom podobne, ako predtým salzburský a pasovský episkopát zasahovali na územiach mimo svojich diecéznych hraníc (v Panónii a na Vel'kej Morave). Metodove legátstvo pre slovanské krajiny tým totiž nezaniklo, takže mohol právoplatne pôsobit’ aj v rámci nových Svätoplukových výbojov. ${ }^{32}$

V Ríme došlo v roku $880 \mathrm{k}$ vytvoreniu samostatnej cirkevnej provincie s organizačnou štruktúrou v rámci územného rozsahu Svätoplukovej Vel'kej Moravy, spadajúcej bezprostredne pod pápežskú jurisdikciu. Tým, že pápež určil Metoda za arcibiskupa tejto provincie a vysvätil Wichinga za jemu podriadeného sídelného nitrianskeho biskupa, ${ }^{33}$ vzt'ahovali sa ich právomoci na konkrétne vymedzené územia. Je temer isté, že tieto územia sa kryli s dvomi základnými súčast’ami ríše - Moravským kniežatstvom a Nitrianskym kniežatstvom. Aj po anexii Nitrianska Mojmírom I. okolo roku 833 Nitra ako správne územie nezaniká, ale jej pôvodná samostatnost' sa premieta do duálneho členenia Vel'kej Moravy. ${ }^{34} \mathrm{~S}$ najväčšou pravdepodobnost'ou bolo Nitriansko údelným kniežatstvom viazaným na osobu predpokladaného následníka na kniežacom stolci. Táto špecifická situácia vo vnútornej štruktúre ríše dala aj základnú štruktúru členenia arcidiecézy. Hranicu diecéz môžeme teda stotožnit's hranicou oboch kniežacích útvarov.

Takto definovaná cirkevná diecézna štruktúra už predpokladala aj príslušné sídelné biskupské chrámy. V prípade Nitrianskeho biskupstva bolo Wichingovo sídlo v Nitre a tu treba situovat' i jeho biskupskú rezidenciu. Kontinuálna stavebná činnost' počas stáročí zničila pôvodné situácie, v ostatnom čase však na základe nálezov stavebných sutín a fragmentov odborníci uvažujú s umiestnením sakrálnej stavby na hradnom vrchu v priestore terajšej katedrály. Nálezy stavebnej sutiny vo vel'komoravskom vale I a maltové zhluky pod ním ${ }^{35}$ dokladajú neznámu murovanú stavbu na vrchole hradného kopca z 1. polovice 9. stor., ktorá mohla byt’ ešte Pribi-

\footnotetext{
${ }^{31}$ Betti, M.: Vznik Sancta Ecclesia Marabensis - listy papeže Jana VIII. (872-882). In Kouřil, P. et al. (eds.): Cyrilometodějská misie a Evropa: 1150 let od př́íchodu soluňských bratř́ na Velkou Moravu. Brno: AÚ AV ČR, 2014, s. 208.

${ }^{32} \mathrm{~V}$ Živote Metoda je napr. zaznamenané pokrstenie vislanského kniežata. Porov. Život Metoda. In Škoviera, A.: Pramene o živote svätých Cyrila a Metoda a ich učeníkov. Bratislava: PostScriptum, 2013, s. 52. Škoviera preberá preklad od Vragaš, Š.: Život Konštantína Cyrila a Život Metoda. Martin: Matica slovenská, 1991.

${ }_{33}$ Vol'bu Nitry zrejme ovplyvnila skutočnost', že bola pravdepodobne sídlom archipresbyteriátu, ustanoveného pasovským biskupom pred príchodom cyrilometodskej misie. Porov. Betti, M.: La formazione della Santa Ecclesia Marabensis (858-882), c. d., s. 174; Judák, V.: Dejiny Nitrianskeho biskupstva. In Judák, V. - Bednár, P. - Medvecký, J. (eds.): Kolíska krest’anstva na Slovensku. Nitriansky hrad a Katedrála sv. Emerána v premenách času. Nitra: Biskupský úrad a AU SAV, 2011, s. 18.

${ }^{34}$ König, T.: The Great Moravian territory of Nitra. Cultural manifestations, territorial scope and the ethnic and socialpolitical identity of its population. In: Muzeológia a kultúrne dedičstvo, 2017, Vol. 5, No. 2, s. 10; König, T.: Nitrianski Slovania a zánik Vel'kej Moravy. In: Od Bachórza do Światpwida ze Zbrucza. Tworzenie sie slowiańskiej Europy w ujeciu źródloznawczym. Ksiega jubileuszowa Profesora Michala parcziewskiego. Kraków: Uniwersytet JagellońskiRzeszów: Uniwersytet Rzeszowski, 2016, s. 182.

${ }^{35}$ Bednár, P.: Nitra v časoch pôsobenia sv. Konštantína - Cyrila a sv. Metoda. In Panis, B. - Ruttkay, M. - Turčan, V. (eds.): Bratia, ktorí menili svet - Konštantín a Metod, c. d., s. 148-149; Bednár, P. - Ruttkay, M.: Nitra. In Kouřil, P. a kol. (eds.): Velká Morava a počátky křest’anství. Brno: AÚ AV ČR, 2014, s. 231.
} 
novým kostolom. ${ }^{36}$ Ďalšia stavebná aktivita je nálezmi doložená do 2. polovice 9. stor. Hradný vrch bol vtedy obohnaný valom a došlo k výraznej prestavbe staršieho objektu. Charakterizuje ju kvádrikové murivo z litotamniového vápenca, druhotne použité v zásype komorového valu z 11. stor. a v murive neskororománskej časti kostola z prelomu 12./13. stor. ${ }^{37}$ Našli sa aj zvyšky dvoch architektonických článkov v sekundárnej polohe s rustikalizujúcou výzdobou - jeden s reliéfom perlovca, druhý s dekoráciou akantových listov, jazykov a l'udských hláv. Uvažuje sa ich súvislost' s karolínskym prostredím 9. stor. ${ }^{38}$ Je vysoko pravdepodobné, že táto prestavba sa uskutočnila v súvislosti so vznikom nitrianskeho biskupstva, ked’že starší Pribinov chrám už nevyhovoval novej reprezentačnej funkcii. Osoba Wichinga dáva možnú spojitost's karolínskou provenienciou architektonických článkov. ${ }^{39}$

Ak v prípade Nitrianskeho biskupstva nie sú pochybnosti o jeho sídle, nejasná je otázka situovania Metodovho sídla a jeho katedrálneho chrámu, ktoré musíme hl'adat' v priestore Moravského kniežatstva. V minulosti sa vyvinula tradícia spájat’ Metodovo sídlo s moravským Velehradom. Najmä v období národnostného útlaku v 19. stor. to znamenalo výrazné posilňovanie slovanského povedomia a dedičstva solúnskych bratov. ${ }^{40} \mathrm{Aj}$ slovenskí veriaci konali púte do Velehradu a rozvíjalo sa tak nielen náboženské, ale aj osobité národné povedomie. ${ }^{41}$ Treba však konštatovat', že stotožňovanie Velehradu s Metodovým sídlom sa nezakladalo na reálnej situácii, nakol'ko Velehrad sa spomína až v roku 1141, pričom v spojitosti s cyrilometodskou tradíciou až na prelome 13. a 14. stor. $^{42}$

Vychádzajúc z formulácie o Wichingovi ako o biskupovi „cirkvi nitrianskej“ je otázne, či má íst' o pomenovanie jeho sídla (Nitry, resp. Nitravy), alebo o pomenovanie územia jeho pôsobnosti - teda Nitrianska. Môžeme predpokladat', že v prípade Metoda formulácia o arcibiskupovi „cirkvi moravskej“ má rovnaký základ. Ak by šlo o meno sídla, mohlo by to viest’ k názoru, že hlavné

\footnotetext{
36 Šalkovský, P.: K územným zoskupeniam slovanských hradov vo včasnom stredoveku. In Jenčík, P. - Staneková, Z. (eds.): Hradiská - svedkovia dávnych čias II. Dolná Mariková: OZ Hradiská, 2019, s. 223. Staršie názory, ktoré predpokladali kniežacie sídlo v Nitre v lokalitách Martinský vrch alebo pri piaristickom kostole, sú prekonané. Porov. Chropovský, B.: Príspevok k problematike cirkevnej architektúry a počiatkoch krest’anstva na Slovensku. In: Monumentorum tutela. Ochrana pamiatok 8. Bratislava: PUSR, 1972, s. 194-195; Šášky, L.: Kamenná krása našich miest. Bratislava: Obzor, 1981, s. 13.

${ }^{37}$ Bednár, P.: Nitra v časoch pôsobenia sv. Konštantína - Cyrila a sv. Metoda, c. d., s. 149; Bednár, P. - Ruttkay, M.: Nitra, c. d., s. 232.

${ }^{38}$ Bednár, P.: Počiatky nitrianskeho hradu. In Judák, V. - Bednár, P. - Medvecký, J. (eds.): Kolíska krest’anstva na Slovensku, c. d., s. 118. Niektorí odborníci datujú druhý z fragmentov do 11. stor.

${ }^{39}$ Stavitelia mohli pochádzat' z niektorej bavorskej dielne. Analogicky môžeme spomenút' stavitel'ov, ktorých zo Salzburgu poslal Pribinovi arcibiskup Liupram na stavbu kostola sv. Hadriána v Blatnohrade. Ratkoš, P.: Pramene k dejinám Vel'kej Moravy, c. d., s. 88. Samozrejme, v Nitre bola zrejme silná franská prítomnost' už pred Wichingovým pôsobením.

${ }^{40}$ Podrobnejšie pozri v Jonová, J.: Cyrilo-metodějská tradice a Velehrad. Cyrilo-metodějské slavnosti na Velehradě v 19. století a v první polovine 20. století. In Letz, R. - Judák, V. (eds): Cyrilometodská tradícia ako spájajúci fenomén. Nitra: Gorazd n. f., kňazský seminár sv. Gorazda, 2020, s. 113-130; Dvorščáková, Z.: Cyrilo-metodská tradícia u Slovákov a Moravanov na prelome 19. a 20. storočia. In Lukáčová, M. - Husár, M. - Ivanič, P. - Hetényi, M. (eds.): Tradícia a prítomnost' misijného diela sv. Cyrila a Metoda. Nitra: Univerzita Konštantína Filozofa v Nitre, 2013, s. $232-243$.

${ }^{41}$ Judák, V.: Cyrilo-metodský odkaz vo forme velehradských unionistických kongresov. In Letz, R. - Judák, V. (eds.): Cyrilometodská tradícia ako spájajúci fenomén, c. d., s. 100-101; Škvarna, D.: Cyrilo-metodský obraz v slovenskej kultúre 19. storočia. Premena tradície na kult a ich podoby. In Panis, B. - Ruttkay, M. - Turčan, V. (eds.): Bratia, ktorí menili svet - Konštantín a Metod, c. d., najmä s. 204-205.

42 Vavř́nek, V.: The Questions of the legendary Welegrad (Veligrad) as the alleged Seat of the Moravian Archbishop Methodius. In: Slovo, časopis Staroslavenskoga instituta u Zagrebu, 2010, No. 60, s. 771 a 774. Velehradský cisterciánsky kláštor bol založený 1205. Jonová, J.: Cyrilo-metodějská tradice a Velehrad. Cyrilo-metodějské slavnosti na Velehradě v 19. století a v první polovine 20. století, c. d., s. 113.
} 
kniežacie i cirkevné stredisko sa volalo Morava, ${ }^{43}$ ked’že jeho meno nie je pramenne doložené. ${ }^{44}$ Sme však toho názoru, že ide o pomenovanie územia podobne, ako pri prvej ordinácii Metoda za arcibiskupa „cirkvi panónskej“, pričom sa tiež jednalo o územné pomenovanie a nie o sídlo. Metod bol vtedy ustanovený na „stolec sv. Andronika“"45 a tým bol Sriem. Sídlo s názvom „Panónia“ nie je vôbec známe.

Metodov arcibiskupský chrám je teda nutné hl'adat' na území dobového moravského kniežatstva. Hranica medzi Nitrianskom a Moravou nie je však celkom jasná, hlavne na jej južnom ukončení. Dnes sa odborníci zhodujú v názore, že hranica oboch kniežatstiev bola na hrebeňoch Malých Karpát. ${ }^{46}$ Otázne je ale vyústenie karpatského horstva v jeho južnej časti na styku s Dunajom, kde na výbežkoch vznikli dva dôležité hradiskové útvary - Devín a Bratislava. Konkrétne, do ktorého celku tieto sídla patrili a či je možné s nimi uvažovat' v súvislosti s Metodovým arcibiskupským stolcom, ked’že na oboch sa objavili sakrálne stavby výnimočného charakteru. ${ }^{47}$ Príslušnost' Bratislavy a Devína riešia odborníci rôzne. V zásade ide o dve úzko previazané lokality, situované na západnom (Devín) a východnom (Bratislava) ukončení „Bratislavskej brány““ ${ }^{48}$ Bratislavu, resp. vel'komoravské hradisko so sídliskom, čast' odborníkov považuje za súčast' Nitrianska ${ }^{49}$ a Devín za súčast' Moravského kniežatstva. ${ }^{50}$ Obe lokality pokladá za súčast’ moravskej ekumény napr. T. König, a to z dôvodu geografického oddelenia územia od Trnavskej platne. ${ }^{51}$ Z oboch lokalít bola významnejšia Bratislava, situovaná na dunajskom brode. Nálezy potvrdzujú, že bola dôležitým správnym i cirkevným strediskom a v blízkosti hradiska bolo sídlisko predmestského typu. ${ }^{52}$ Dokonca F. V. Sasinek v 19. stor. uvažoval o Bratislave ako s biskupstve v súvislosti s obnovením vel'komoravskej provincie po roku $899 .{ }^{53}$

\footnotetext{
${ }^{43}$ Názov Morava považujú niektorí za meno sídla i územia. Napr. Selucký, P.: Sv. Kliment u Osvětiman a Velká Morava. Koryčany: autorské vydanie, 2010, s. 97.

${ }^{44}$ Okrem nejasného pomenovania $v$ arabských prameňoch Ch.rdáb, Ch.ž.rát, Dž.r.wáb a Dž.ráv.t. Súhrnne: Selucký, P.: Sv. Kliment u Osvětiman a Velká Morava, c. d., s. 87. Názvy typu „Katon“, „Kanaon“ a pod., uvedené v neskorších cyrilských písomnostiach, zachovaných od 13. stor., sa považujú za skomoleninu názvu „Panónia“. Bartoňková, D. Večerka, R. (eds.): Magnae Moraviae fontes historici II. Textus biographici, hagiographici, liturgici. Editio secunda, revisa et aucta. Prameny k dějinám Velké Moravy II. Texty biografické, hagiografické, liturgické. Druhé revidované a rozšířené vydání. Praha: KLP, 2010, s. 242.

${ }^{45}$ Život Metoda. In Škoviera, A.: Pramene o živote svätých Cyrila a Metoda a ich učeníkov, c. d., s. 51.

${ }^{46}$ Vavák, J.: Včasnostredoveké hrady na juhozápade Malých Karpát. Ich vznik, význam a úloha. In Jenčík, P. - Struhár, V. (eds.): Hradiská - svedkovia dávnych čias. Dolná Maríková: OZ Hradiská, 2015, s. 107.

${ }^{47} \mathrm{Na}$ Devíne je to kostol ukončený trikonchou, odvodzovaný od dalmátskych vzorov ako výsledok aktivít kniežata Rastislava. Illáš, M.: Vzt’ah predrománskeho kostola na Devíne k dalmátskej architektúre. In: Konštantínove listy/ Constantine's letters, 2018, roč. 11, č. 2, s. 25. Bratislavská trojlod'ová bazilika nemá zachované východné ukončenie. Všeobecne sa tiež považuje za prejav adriatických vzorov (napr. Štefanovičová, T.: Bratislavský hrad v 9.-12. storočí. Bratislava: Obzor, 1973, s. $72-74$ a inde). Zachovaná dispozícia však umožňuje poukázat' aj na analógie vo franskom prostredí (Botek, A.: Vel'komoravská bazilika na Bratislavskom hrade. In: Verbum historiae, 2014, roč. 2, č. 1, s. 30).

${ }^{48}$ Štefanovičová, T.: Bratislava a Devín. In Kouřil, P. a kol. (eds): Velká Morava a počátky křest’anství. Brno: AÚ AV ČR, 2014, s. 244.

${ }^{49}$ Napr. J. Steinhübel považuje Bratislavu za prvé hradisko Nitrianskeho kniežatstva na juhu. Steinhübel, J.: The Nitrian Principality. The Beginnings odf Medieval Slovakia. Leiden: Brill, 2020, s. 182.

${ }^{50}$ Vavák, J.: Včasnostredoveké hrady na juhozápade Malých Karpát. Ich vznik, význam a úloha, c. d., s. 107. Autor dokonca uvažuje o ich vzájomnej konkurencii. M. Ruttkay Bratislavu považuje za súčast' Nitrianska, ale v prípade Devína nemá jednoznačný argument na jeho príslušnost'. Ruttkay, M.: Mocenské centrá Nitrianskeho kniežatstva. In Panis, B. - Ruttkay, M. - Turčan, V. (eds.): Bratia, ktorí menili svet - Konštantín a Metod, c. d., s. 132.

${ }^{51}$ König, T.: The Great Moravian territory of Nitra. Cultural manifestations, territorial scope and the ethnic and socialpolitical identity of its population, c. d., s. 14 .

52 Štefanovičová, T.: Bratislava a Devín, c. d., s. 244.; Šášky, L.: Bratislava, mesto na Dunaji. Bratislava: Smena, 1992, s. 46-47.

53 Sasinek, F. V.: Dejiny drievnych národov na území terajšieho Uhorska. Skalica: F. X. Škarnicla, 1867, s. 203, Dostupné online: https://books.google.sk/books?id=iqkJAAAAIAAJ\&printsec=frontcover\&redir_ $\mathrm{esc}=\mathrm{y} \# \mathrm{v}=$ onepage $\& \mathrm{q}=$ Gorazd $\& \mathrm{f}=$ false
} 
Niektorí bádatelia vyjadrili presvedčenie, že Metod v období, ked' bol titulárnym panónskym arcibiskupom (869-880), vôbec nemusel mat' pevný sídelný chrám. ${ }^{54}$ Ako moravský arcibiskup ho už jednoznačne mal, je to zaznamenané pri opise jeho úmrtia v Živote Metoda, XVII: „A len čo ho jeho učeníci opatrili a vzdali mu dôstojné pocty, vykonali cirkevnú službu po latinsky, grécky a po sloviensky a uložili ho v katedrálnom chráme. “. ${ }^{55} \mathrm{~V}$ neskoršom prameni - Proložnom živote Konštantína a Metoda - je doplňujúci údaj: „Leží vo vel'kom chráme moravskom na lavej strane v stene za oltárom svätej Bohorodičky".${ }^{\text {". }}$

V minulosti boli rôzne úvahy ohl'adne sídla arcibiskupa Metoda založené na analýzach písomných prameňov, lokálnych tradícií, názvov či iných zdrojov nehmotného charakteru. Od polovice 20. stor. je z archeologických nálezov známych na území Slovenska, Moravy a Čiech už skoro 30 sakrálnych objektov, resp. ich fragmentov, pričom štyri stoja v hmote zachované dodnes. ${ }^{57}$ Je teda možné skromné písomné údaje komparovat's architektonickými charakteristikami objektov. Zohl'adnit' treba okolnost', že Metodov katedrálny chrám by mal mat' reprezentačný charakter a obsahovat' aj arcibiskupov hrob, pričom však tento môže byt' aj prázdny. ${ }^{58} \mathrm{Na}$ základe skreslených obvinení totiž pápež Štefan V. listom z apríla 885 odsúdil Metodove údajné prečiny a zakázal starosloviensku liturgiu. Súčasne však vyjadril isté pochybnosti, ktoré vidno z formulácií ,...vel'mi sme sa podivili, ak je tomu tak, ako sme počuli, jeho blud zavrhujeme....".59 Franskí kňazi považovali zrejme Metoda za heretika a Metodovi učeníci, v obave pred zneuctením jeho pozostatkov, ich mohli preniest' na iné miesto. Každopádne by aj v takom prípade ale ostalo hrobové miesto.

Vzhladom na uvedené kritériá musíme vylúčit Devín a Bratislavu, aj keby boli patrili do moravského kniežatstva. Na Devíne sa vel'komoravské hroby našli len južne od kostola, nie však $\mathrm{v}$ jeho interiéri. ${ }^{60} \mathrm{~V}$ bratislavskej bazilike sa $\mathrm{v}$ interiéri v zachovanej časti nachádzajú len 2 hroby, ktoré síce autorka výskumu považuje za mladšie, ${ }^{61}$ ale ich vel'komoravský pôvod nie je dostatočne vylúčený. ${ }^{62}$ Žiaden z hrobov však nezodpovedá výnimočnosti postavenia nebožtíka ani zmie-

\footnotetext{
${ }^{54}$ Jan, L.: Počátky moravské církevní organizace a charakter Metodějova arcibiskupství. In Kouřil, P. et al. (eds.): Cyrilometodějská misie a Evropa: 1150 let od příchodu soluňských bratř́i na Velkou Moravu. Brno: AÚ AV ČR, 2014, s. 203.

${ }_{55}$ Život Metoda. In Škoviera, A.: Pramene o živote svätých Cyrila a Metoda a ich učeníkov, c. d., s. 55.

${ }^{56}$ Proložnoje žitije Konstantina i Mefodija/Proložní život Konstantinův a Metodův. In Bartoňková, D. - Večerka, R. (eds.): Magnae Moraviae fontes historici II. Textus biographici, hagiographici, liturgici. Editio secunda, revisa et aucta. Prameny k dějinám Velké Moravy II. Texty biografické, hagiografické, liturgické. Druhé revidované a rozšířené vydání. Praha: KLP, 2010, s. 143. Preklad do slovenčiny autor. Dielo je známe z odpisov z 13. a 14. stor., vzniklo podl’a všetkého ešte počas existencie cyrilo-metodskej školy.

${ }_{57} \mathrm{Na}$ Slovensku kostoly pri Kopčanoch, V Kostol'anoch pod Tribečom a rotunda nad Nitrianskou Blatnicou (Botek, A.: Kostol sv. Margity Antiochijskej v Kopčanoch. Úpravy v priebehu vývoja, prezentácia a interpretácia hodnotných vrstiev. In: Zborník prednášok 17. medzinárodného seminára o reštaurovaní. Senica: RESTAU ART, 2019, s. 96-97; Barta, P. - Bóna, M. - Keleši, M.: Chronometrický výskum murív kostola sv. Juraja v Kostol'anoch pod Tribečom. In: Archaeologia historica, 2015, roč. 40, č. 1, s. 691-709; Dorica, J.: Reštaurovanie rotundy sv. Juraja pri Nitrianskej Blatnici. In: Pamiatky a múzeá, 2017, roč. 66, č. 3, s. 34). K nim možno priradit' v Česku rotundu v Budči zo začiatku 10. stor. (Illáš, M.: Niektoré stavebno-technické a výtvarné detaily zachovaných predrománskych kostolov v Čechách a na Slovensku v kontexte karolínskej architektúry. In: Príbehy pamiatok a obrazov. Zborník príspevkov k sedemdesiatinám Ivana Gojdiča. Trnava: Filozofická fakulta Trnavskej univerzity v Trnave, 2018, s. 137).

${ }^{58}$ Súhrnne k problematike Metodovho hrobu: Botek, A.: Die Frage des Grabes von Erzbischof Method im Zusammenhang mit der bekannten grossmährischen Sakralarchitektur. In Historia Ecclesiastica, 2020, roč. XI, č. 2, s. 3-19.

${ }^{59}$ Bartoňková, D. - Večerka, R. (eds.): Magnae Moraviae Fontes Historici III, c. d., s. 189; Ratkoš, P.: Pramene k dejinám Vel'kej Moravy, c. d., s. 199.

${ }^{60}$ Hanuliak, M.: Pohrebný rítus na Vel'kej Morave. In Kouřil, P. a kol. (eds): Velká Morava a počátky křest’anství. Brno: AÚ AV ČR, 2014, s. 92, obr. 1B.

${ }^{61}$ Štefanovičová, T.: Bratislavský hrad v 9.-12. storočí, c. d., s. 76.

${ }^{62}$ Illáš, M.: Nový pohl'ad na stavebný vývoj sakrálnych stavieb na Bratislavskom hrade. In: Verbum historiae, 2020, č. 8, s. 160 a 170, obr. 1. Illáš prehodnotil doterajšie publikované nálezové situácie hrobov a zaujal k ich interpretácii kritické stanovisko.
} 
nenému opisu, oba sú bez nálezov. Objekt sa však nezachoval vo východnej časti, a tak hypoteticky možno pripustit’ takúto nezachovanú situáciu v zaniknutom priestore. Rovnako možno vylúčit' kostol č. 1 na Pohansku, ked’že sa jednalo o vlastnícky kostol v rámci vel'možského areálu. ${ }^{63}$

Z lokalít, situovaných na Morave, poznáme viacero sakrálnych objektov, ktoré svojou vel'kost’ou, dispozíciou či členením odrážajú výnimočnejší - reprezentatívnejší význam. Ak zoberieme do úvahy jestvujúce vel'komoravské chrámy vzhl'adom na ich vel'kost' vrátane neskorších prístavieb, pričom predpokladáme, že táto je odrazom reprezentatívnosti, vyjde nasledujúca skupina: Kostol č. 3. - Valy pri Mikulčiciach (bazilika), chrámový kompex v Sadoch (Uherské Hradište), kostol v lokalite Špitálky (Staré Město) a kostol č. 1. na Pohansku. Trikonchu na Devínskom hrade a bratislavskú baziliku (ktorá síce nie je zachovaná v celom rozsahu, ale vzhl'adom na jestvujúcu substanciu šlo iste o rozmerný objekt) sme už z úvah vylúčili. V sídliskovej aglomerácii Valy pri Mikulčiciach sa doposial' zistilo 12 kostolov, resp. ich fragmentov. ${ }^{64}$ Medzi nimi je aj najväčší sakrálny objekt na území bývalej ČSR - Kostol č. 3 - bazilika s predsieňou a átriom. Vo všeobecnosti sa považuje za kniežaciu baziliku, avšak vyskytuje sa názor, že šlo o biskupský kostol. ${ }^{65}$ Celkový pôdorys je výsledkom vývoja v rámci 9. stor. Svojím hmotovo - dispozičným riešením by zodpovedal reprezentačnej funkcii arcibiskupského chrámu. Z mnohých hrobov, ktoré sa našli v jeho interiéri, upútal hlavne na artefakty bohatý hrob č. 580, situovaný približne v strede hlavnej lode pri jej styku so severnou, označený autorom výskumu ako vel'možský hrob. ${ }^{66}$ Neskôr Z. Klanica publikoval názor, že ide o hl'adaný Metodov hrob ${ }^{67}$ táto interpretácia však nie je medzi odborníkmi prijatá. Umiestnenie hrobu nezodpovedá situácii „,v stene“ a aj ostatné fakty odporujú opisovanému pochovaniu. ${ }^{68}$ Najmä nie je myslitel'ný výskyt militárií a profánnych predmetov v hrobe vysokého cirkevného hierarchu byzantskej obediencie. ${ }^{69}$ Vzhl'adom na uvedené skutočnosti musíme v tejto chvíli lokalitu Valy pri Mikulčiciach ako možné Metodove arcibiskupské sídlo vylúčit’. Kostol v lokalite „Špitálky“ vykazuje v druhej stavebnej fáze úpravy umožňujúce uvažovat' s byzantským stavitel’ským vplyvom (najmä možná dostavaná kopula) ${ }^{70}$ neobsahuje však hrobové miesto príslušných parametrov. Treba však poznamenat', že z objektu sa zachovala len severná polovica základov, takže hypoteticky takýto hrob sa mohol nachádzat’ v zničenej južnej polovici. V ostatnom čase sa vyskytol názor, že ide o stavbu vedome ovplyvnenú byzantským stavitel'stvom, ktorá bola pravdepodobne súkromným kostolom kniežat’a Rastislava. ${ }^{71}$

\footnotetext{
${ }^{63}$ Macháček, J.: Byzantská misie a doklady jejího působení na Pohansku u Břeclavi. In Kouřil, P. et al. (eds.): Cyrilometodějská misie a Evropa: 1150 let od příchodu soluňských bratř́i na Velkou Moravu. Brno: AÚ AV ČR, 2014 , s. 93. ${ }^{64}$ Najmä interpretácia fragmentov je otázna, takže skutočný počet môže byt' cca o 2-3 kostoly menší, Botek, A.: Vel'komoravské kostoly na Slovensku a odraz ich tradície v neskoršom období. Bratislava: PostScriptum, 2014, mapa na s. 28.

${ }^{65}$ Poláček, L.: Mikulčice. In Kouřil, P. a kol. (eds): Velká Morava a počátky křest’anství. Brno: AÚ AV ČR, 2014 , s. 176.

${ }^{66}$ Poulík, J.: Mikulčice. Sídlo a pevnost knížat velkomoravských. Praha: Academia, 1975, s. 77.

${ }^{67}$ Klanica, Z.: Tajemství hrobu velkomoravského arcibiskupa Metoděje. Praha: Futura, 1994.

${ }^{68}$ Klanicov názor uchopil pravoslávny teológ P. Aleš, ktorý situovanie a súvislosti uvedeného hrobu s architektúrou popísal teologicky prijatel'nejšie. Fragmenty meča a dýky určil za zvyšky biskupskej berly a žezla, taktiež ale nevysvetlil výskyt ostatných profánnych predmetov v hrobe (vedierko, sekera atd'.), ktoré samé osebe vylučujú hrob cirkevného hodnostára (Aleš, P.: Kde byl pohřben svatý Metoděj, arcibiskup velkomoravský? Dostupné na internete : https://www. orthodoxia.cz/c_m/hrob_met.htm (Cit. 2021. 19. 06.).

${ }^{69}$ Byzantskí duchovní vôbec nesmeli nosit’ zbrane. Ak by bola pravdivá Alešova interpretácia, že namiesto meča a dýky ide o berlu a žezlo, ostávajú ešte d’alšie sekulárne predmety, nepatričné v hrobe arcibiskupa. Sekera všeobecne svedčí skôr o pretrvávaní predkrest'anskej symboliky mužskej sily a vedro môže súvisiet' s jazdeckým statusom pochovaného. Hájnik, J.: Včasnostredoveké sekerovité hrivny z územia strednej Európy. In: Musaica archaeologica, 2019, roč. 4, č. 2, s. 124.

${ }^{70}$ Galuška, L.: Křest’anství v období byzantské misie a Metodějova arcibiskupství na bázi archeologických pramenů z oblasti Veligradu - Starého Města a Uherského Hradiště. In Kouřil, P. et al. (eds.): Cyrilometodějská misie a Evropa: 1150 let od př́íchodu soluňských bratř́i na Velkou Moravu. Brno: AÚ AV ČR, 2014, s. 80.

${ }^{71}$ Illáš, M.: Kritický pohl'ad na vplyv byzantskej architektúry na sakrálnu architektúru Vel'kej Moravy. In Letz, R. Judák, V. (eds.): Cyrilometodská tradícia ako spájajúci fenomén, c. d., s. 269-270.
} 
Medzi odborníkmi sa už dávnejšie ustálil názor, že ústredné cirkevné stredisko vel'komoravskej arcidiecézy (a teda Metodovo sídlo) bolo v lokalite Sady v aglomerácii Staré Město - Uherské Hradiště. ${ }^{72}$ Bol tu archeologicky objavený sakrálny komplex s kostolom so zložitou dispozičnou štruktúrou, ned’aleko od neho kruhová studňovitá stavba (baptistérium?) a dlhá zrubovitá stavba - pravdepodobný kláštor s cirkevnou rezidenciou. ${ }^{73}$ Chrámová dispozícia pozostáva z viacerých, postupne pristavovaných častí: najstarší je „východný kostol“ krížovej schémy s rovným presbytériom, na západne zväčšený o priestor ukončený oblou apsidou, na severnej strane so samostatným mauzoléom $\mathrm{s}$ apsidou a d’alším priestorom zrejme taktiež hrobového charakteru. Medzi odborníkmi prevláda názor, že krížová čast' kostola s rovným záverom pochádza z obdobia pôsobenia bavorských misionárov a západná dostavba s apsidou a sekundárnou predoltárnou priečkou je dielo stavebnej dielne, ktorú so sebou z Byzancie priviedli Konštantín a Metod. ${ }^{74}$ To tiež býva používané ako argument $\mathrm{v}$ prospech určenia kostola ako Metodovho katedrálneho chrámu. Treba však súčasne poznamenat', že v dôsledku zachovania výlučne základového muriva nie je možné posudzovat' tvaroslovné charakteristiky, a preto sú prípustné i iné interpretácie. Bol publikovaný názor, že tu ide o typ karolínskeho dvojchórového kostola ${ }^{75}$ vzniknutého sekundárnou prístavbou $\mathrm{k}$ staršej časti. ${ }^{76}$ Uvedená západná prístavba obsahovala v apside za priečkou hrob zrejme významného jedinca, nie je však v literatúre dávaný do súvislosti s pochovaním arcibiskupa Metoda, ked’že nekorešponduje so známymi údajmi. Podobne je to s výnimočným hrobom v severnom mauzóleu, hypoteticky umožňujúcim uvažovat' o hrobke kniežata Svätopluka. ${ }^{77}$

Hrobová dutina, resp. jej dno, bola objavená v základovom murive južnej steny presbytéria „krížovej“ časti kostola. Vysekaná bola z vnútornej strany, z exteriéru zabezpečená statickou prímurovkou, $\mathrm{v}$ interiéri podla úlomkov predpokladal autor výskumu prekrytie mramorovou platňou a stotožnil nález s Metodovým hrobom. ${ }^{78}$ Uvedený názor zastáva aj súčasný výskumník tejto lokality L. Galuška. ${ }^{79}$ Absencia telesných ostatkov je vysvetl’ovaná možným vyplienením hrobu počas mad’arských nájazdov začiatkom 10. stor., alebo uložením na inom mieste z obavy Metodových učeníkov pred jeho zneuctením. Prísne vyjadrenie pápeža Štefana V. voči Metodovi (krivo obvinenému z herézy a porušovania prísahy) mohlo byt' zámienkou franskému kléru pre odstránenie pozostatkov „heretika“ z posvätného chrámového priestoru. Galuškov a Hrubého názor bol odborníkmi akceptovaný ako vysoko pravdepodobný, hoci sa vyskytli i námietky najmä technického charakteru. ${ }^{80} \mathrm{O}$ funkcii sadskej výšiny ako cirkevného centra svedčí aj viacero indícií a nálezov, mimo iných i stylusy, používané v pisárskom prostredí. Úlomky skiel z pre-

\footnotetext{
${ }^{72}$ Galuška, L.: Křest’anství v období byzantské misie, c. d., s. 83.

${ }^{73}$ Galuška, L.: Staré Město - Uherské Hradiště. In Kouřil, P. a kol. (eds.): Velká Morava a počátky křest’anství. Brno: AÚ AV ČR, 2014, s. 182.

${ }^{74}$ Galuška, L.: Křest’anství v období byzantské misie, c. d., s. 81.

${ }^{75}$ Používané hojne najmä od aachenskej synody z roku 817. Vančo, M.: Funkcie vel'komoravských kostolov vo vzt’ahu k pohrebiskám. In Panis, B. - Ruttkay, M. - Turčan, V. (eds.): Bratia, ktorí menili svet - Konštantín a Metod, c. d., s. 108. ${ }^{76}$ Pomfyová, B.: Liturgický kontext ranostredovekej architektúry. In: Ars, roč. 38, č. 2, s. 120-121; Illáš, M.: Kritický pohl'ad na vplyv byzantskej architektúry na sakrálnu architektúru Vel'kej Moravy, c. d., s. 250-251.

${ }^{77}$ Galuška, L.: Uherské Hradiště - Sady. Křest'anské centrum říše Velkomoravské. Brno: Moravské zemské muzeum, 1996, s. 125 .

${ }^{78}$ Hrubý, V.: Hrob svatého Metoděje v Uherském Hradišti - Sadech. In: Slovenská archeológia, 1970, roč. XVIII, č. 1, s. 92.

${ }^{79}$ Galuška, L.: Uherské Hradiště - Sady. Křest’anské centrum říše Velkomoravské, c. d., s. 122.

${ }^{80}$ Napr. Z. Špičák poukazuje na technické t’ažkosti s vysekaním hrobu do základov, ako i so statickými problémami, podtekaním a pod., pričom nález považuje za zvyšok sekundárneho exploatovania kamenného materiálu. Pozri Špičák, Z.: Úvaha k problematice jižní zdi apsidy kostela v Uherském Hradišti - Sadech. In: Sborník prací Filozofické fakulty Brněnské univerzity. Studia minora Facultatis philosophicae Universitatis Brunensis. Brno: Filosofická fakulta, 2000, roč. 49, č. M 5, s. 133-162.
} 
nosných lámp zasa poukazujú na ich byzantský charakter, ${ }^{81}$ čo umocňuje argumenty v prospech sídla byzantskej misie, resp. Metoda.

Zaujímavá je i otázka vzt’ahu centrálneho cirkevného a kniežacieho centra. Pokial' prijmeme všeobecný názor, že hlavným kniežacím sídlom boli Valy pri Mikulčiciach musíme akceptovat' teritoriálnu rozdielnost' oboch dôležitých centier ríše. Musíme však konštatovat', že z dobových záznamov nevieme presne určit', či vel'komoravský vládca používal jedno stabilné sídlo, alebo - podobne ako franskí panovníci - sa presúval po krajine a postupne sa zdržiaval na rôznych miestach. Myslíme si však, že je možné pripustit’ i tézu, že obe centrá boli blízko seba - konkrétne cirkevné stredisko v lokalite Sady (Uherské Hradište) a kniežacie v priestore dnešného Starého Města. Oba útvary dnes tvoria jeden urbanistický celok a aj vo vel'komoravskej dobe boli v podstate jednou aglomeráciou. Kontinuálna stavebná činnost' neumožňuje dospiet' k takým plošným výsledkom o dobovej zástavbe, ako v prípade Valov pri Mikulčiciach, ktoré zánikom Vel’kej Moravy spustli a sídlisko postupne zaniklo. Napriek tomu nálezy dostatočne preukazujú dôležitost' tejto aglomerácie ${ }^{82} \mathrm{v}$ ktorej poznáme doteraz pät' sakrálnych stavieb a niekol'ko d'alších, t’ažko datovatel'ných. Ak by sme pripustili centrálnu kniežaciu úlohu Starého Města, vysvetlíme tým i predsmrtnú komunikáciu Metoda so Svätoplukom, z ktorej vyplýva, že obaja sa zdržiavali alebo na spoločnom mieste, alebo vo vzájomne blízkych lokalitách.$^{83}$ Väčšiu váhu by dostala aj už spomenutá hypotéza pochovania Svätopluka v mauzóleu, pristavanom severne k sadskému kostolu.

\section{Záver}

Na Vel'kej Morave rástol názorový konflikt medzi Metodom a bavorským klérom, ktorý začal presahovat' hranice výsostne náboženského hl'adiska a hrozil dôsledkami i vo vnútornej stabilite krajiny. Roku 879 poslal Svätopluk do Ríma svojho radcu Jána z Benátok, ktorý informoval nielen o spore, ale aj o Svätoplukových pochybnostiach v oblasti vierouky, spôsobených zrejme týmto sporom. Pravdepodobne aj franskí kňazi adresovali rímskej kúrii svoje st’ažnosti. Následne pápež Ján VIII. povoláva Metoda (ako arcibiskupa ,cirkvi panónskej“) do Ríma, kam sa dostavil v oficiálnom posolstve s vel'možom Zemežízňom. V Ríme dosiahlo posolstvo podstatný úspech na cirkevnom i spoločensko - politickom poli. Pápež vzal Svätopluka a jeho ríšu pod patronáciu Ríma, v čom najmä starší autori videli nezávislé postavenie Vel'kej Moravy v medzinárodno-politickom aspekte. Súčasne sa Metod vo všetkom obhájil, pápež opätovne schválil používanie staroslovienskej liturgie (aj ked' s istým obmedzením) a Metoda ustanovil za arcibiskupa „svätej cirkvi moravskej“. Súčasne vysvätil za biskupa pre Nitru Svätoplukovho dôverníka, franského benediktína Wichinga. Týmto sa de facto ustanovila vel'komoravská cirkevná provincia s pevnou štruktúrou v rámci územia ríše, čo môžeme vnímat’ ako dôsledok politickej patronácie. Pápež súčasne vyzval Svätopluka, aby poslal i iného vhodného kandidáta na biskupa, čím by sa uvedená arcidiecéza stala plne funkčnou a sebestačnou aj na cirkevno-jurisdikčnom poli. Až od tejto chvíle sa mení Metodove vol'né titulárne určenie panónskeho arcibiskupa, ktoré ani na území Panónie reálne nemohol vykonávat'. Metod sa z titulárneho arcibiskupa s vol'nejšími kompetenciami stáva arcibiskupom sídelným. Vel'ká Morava sa mení z prevažne misijného územia, resp. územia s výkonom právomoci pápežského legátstva, na samostatnú cirkevnú provinciu podliehajúcu priamo pápežskej kúrii.

\footnotetext{
${ }^{81}$ Galuška, L.: Křest’anství v období byzantské misie, c. d., s. 82.

${ }^{82}$ Menoušková, D.: Sedmdesát let archeologických výzkumů středohradištních lokalit na Uherskohradištsku a současný stav poznání tzv. Ostrova sv. Jiří. In: Archaeologia Historica, 2020, roč. 45, č. 2, s. 818.

${ }^{83}$ Život Klimenta. In Škoviera, A.: Pramene o živote svätých Cyrila a Metoda a ich učeníkov. Bratislava: PostScriptum, 2013, s. 108. Škoviera preberá preklad od Stanislav, J.: Osudy Cyrila a Metoda a ich učeníkov v Živote Klimentovom. Bratislava: Tatran, 1950, s. 63-126.
} 
Sme presvedčení, že zmena pápežskej optiky, ku ktorej tu došlo, nebola výsledkom pápežovho pôvodného zámeru, ale návrhom zo strany vel'komoravskej delegácie.

Jednoznačná územná štruktúra vyžaduje aj pevné sídla cirkevných hierarchov. Súčasne sa v uvedenom cirkevnom členení odráža i duálny charakter ríše v zmysle Moravy a Nitrianska. V prípade Wichinga bola biskupským sídlom jednoznačne Nitra, i ked' vzhl’adom na kontinuálny stavebný vývoj sa architektúra biskupských stavieb zničila. Aj na základe ostatných výskumov však možno tvrdit', že toto sídlo s chrámom sa nachádzalo v priestore dnešnej hradnej katedrály. Metodovo sídlo musíme hl'adat' v oblasti Moravského kniežatstva. Z dobových i dobovo inšpirovaných textov vieme aj o skutočnosti pochovania Metoda v jeho katedrálnom chráme „V stene na l'avej strane za oltárom Bohorodičky“. Pri hl'adaní Metodovej katedrály musíme brat' do úvahy nielen územnú charakteristiku či reprezentatívnost' sakrálnej stavby, ale aj hrobové miesto, resp. jeho zvyšky, zodpovedajúce príslušnému popisu. Preto musíme vylúčit' kostoly na Bratislavskom i Devínskom hrade, ktorých príslušnost' k moravskej časti je sporná a ani neobsahujú relevantne umiestnený hrob. Podobne sa vylučujú i kostoly v Pohansku a v lokalite „Špitálky“ (Staré Město), hoci posledne menovaný javí jednoznačné prvky byzantského architektonického riešenia. Samozrejme, v priebehu času sa vyskytlo množstvo rôznych teórií o situovaní Metodovho hlavného chrámu. Najpravdepodobnejším miestom sídla arcibiskupa Metoda je podl'a všetkého lokalita „Sady“v aglomerácii Staré Město - Uherské Hradiště. Obsahuje chrámový komplex zložitej dispozície, pril'ahlú rozmernú stavbu (rezidenciu s kláštorom?), krytú studňu (baptistérium?) a d'alšie objekty. V južnej stene presbytéria sa našla spodná úroveň hrobovej dutiny, ktorá by situovaním najlepšie zodpovedala zaznačenému opisu. Názor, že hl'adaný hrob je v bazilike - Kostole č. 3 na mikulčických Valoch, je nutné odmietnut' z dôvodu svetského charakteru pochovanej osoby. Ak prijmeme lokalitu „Sady“ za cirkevné centrum ríše, ostáva otázka centra svetskej moci. Väčšina autorom za hlavné kniežacie sídlo považuje Valy pri Mikulčiciach. Uvádzame d'alšiu hypotézu, že hlavné centrum mohlo byt' v priestore dnešného Starého Města, čo by znamenalo blízke susedstvo oboch najvyšších správnych sídel.

\title{
Method, Archbishop of the „Moravian Church“6 and the (Great)Moravian Cathedral
}

\author{
Andrej Botek
}

In Great Moravia, a conflict between the archbishop Method and the Bavarian clergy grew. As results of this tension pope John VIII. summoned Method in June 879 from Great Moravia to Rome. In his letter, he named Method as „Archbishop of the holy Pannonian Church“. Method travelled as member of the official embassy with the nobleman Zemežízeň. In Rome, the message was a significant success in both the ecclesiastical and socio-political fields. The pope took ruler Svätopluk and his territory under the patronage of Rome. Method defended himself and pope appointed him archbishop of the „Holy Moravian Church „,. At the same time, he ordained the bishop for Nitra, Svätopluk's confidant, the Frankish Benedictine Wiching. This de facto established a Great Moravian ecclesiastical province with a solid structure. Method until that time the titular archbishop with freer competencies became the resident archbishop. It means he had to have his seat with the archbishop's temple. Wiching had his seat in Nitra. Based on researches, it can be claimed that this seat with the church was located in the area of today's castle cathedral. We must look for the Method's seat in the area of the Moravian Principality. Method was buried in his cathedral, in the wall to the left of the altar of the Virgin Mary". This description could be helped in the analysis of remains of known Great Moravian churches. Concerning analyses, we must reject the churches in Bratislava and Devín castles, Church N. 3 in Valy (Mikulčice), Chuch in "Špitálky" etc. It is perhaps the locality "Sady" in Uherské Hradiště as Method's residence. In the south wall of the archeological founded church, the rest of a grave was discovered. The political center is assumed at Valy (Mikulčice), but it could be also in Staré Město near Uherské Hradiště. 


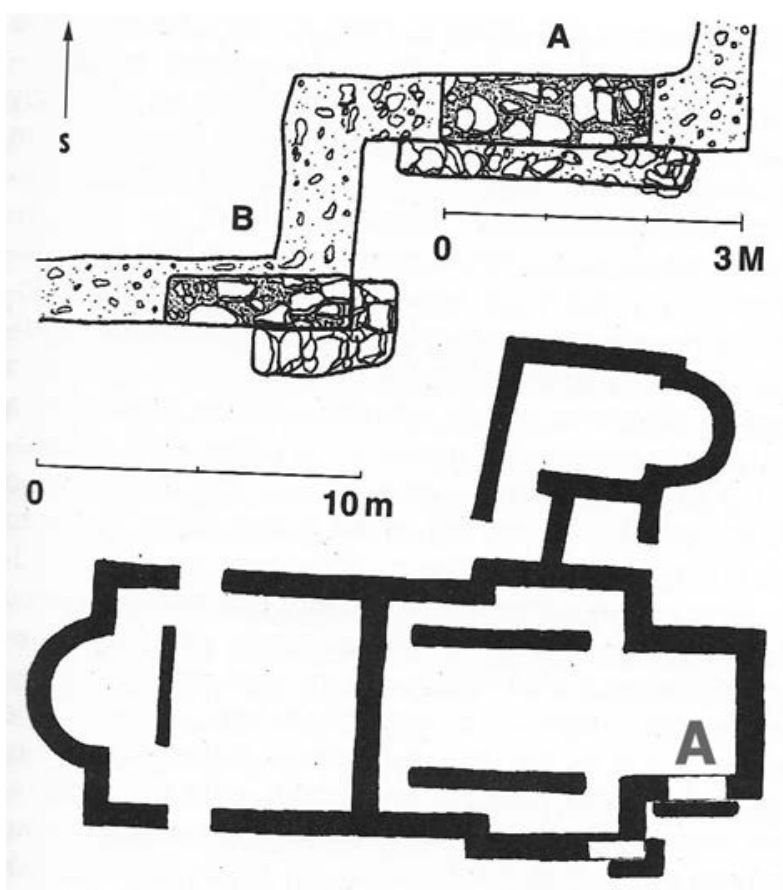

Obr. 1. Pôdorys sakrálneho komplexu v lokalite Sady - Uherské Hradište. Predpokladaný Metodov hrob označený „A“. Zdroj: Galuška, L.: Uherské Hradiště - Sady.

Křest’anské centrum říše Velkomoravské, c. d., s. 119. obr. 75. Úprava: A. Botek.

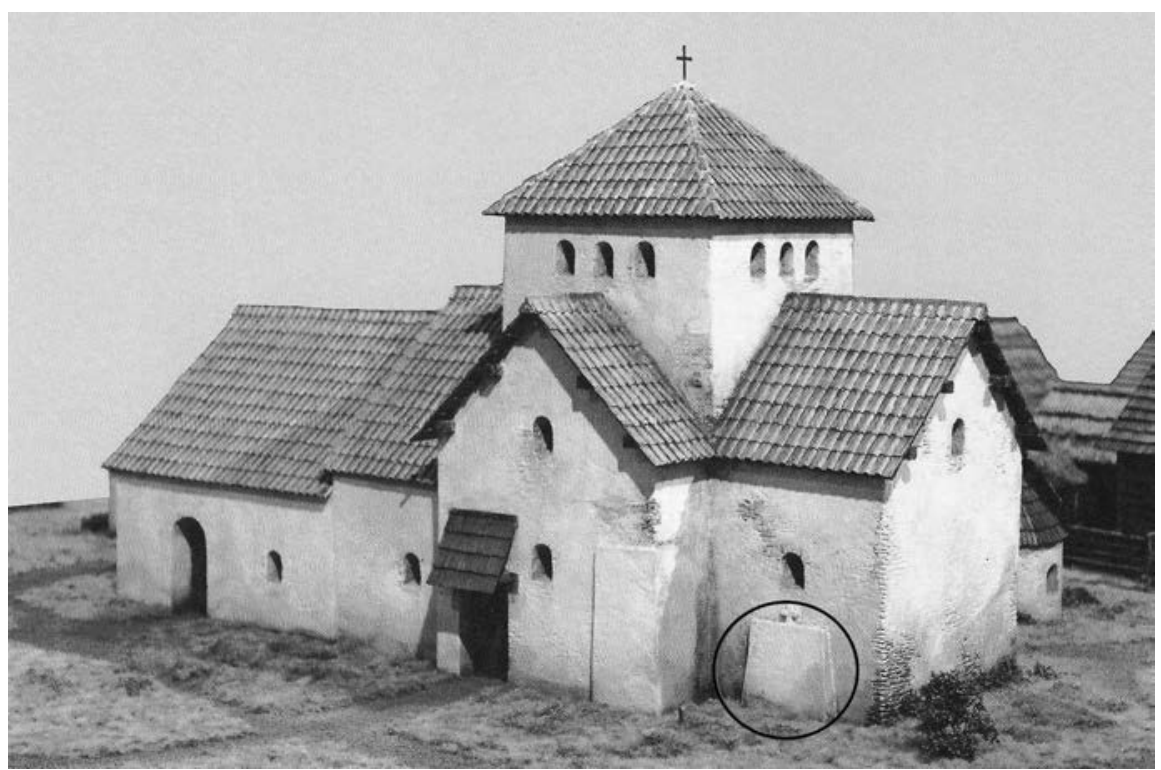

Obr. 2. Model predpokladaného arcibiskupského chrámu v lokalite Sady - Uherské Hradiště. V stene presbytéria označená prímurovka hypotetického Metodovho hrobu.

Zdroj: Galuška, L.: Křest’anství v období byzantské misie..., c. d., s. 76, obr. 2. Úprava: A. Botek. 